\begin{tabular}{l|l} 
Notaice & e-ISSN: 2655-9404 p-ISSN: 2721-8376 \\
Vol. 4 No. 1, Februari 2021 & DOI: 10.20473/ntr.v4i1.22805 \\
\hline
\end{tabular}

Article history: Submitted 26 October 2020; Accepted 13 November 2020; Available online 1 February 2021.

\title{
Jalan Panjang Pengakuan Kesatuan Masyarakat Hukum Adat Melalui Peraturan Daerah: Beberapa Persoalan yang Belum Selesai
}

\author{
Ikhana Indah Barnasaputri \\ ikhana.indah@gmail.com \\ Universitas Airlangga
}

\begin{abstract}
Recognition for indigenous peoples is very important. Such recognition will promote the existence of indigenous people to be protected by law as well as protection of their rights for land. This journal will analyze the initial process of recognition, practice and implementation of recognition and post emergence of local regulation on the recognition of indigenous people. Research method of the journal is normative legal research with a statue approach and conceptual approach. The writing of the journal applies grammatical interpretation and systematic interpretation. The research result in the journal is an attempt of protection and fulfillment of indigenous people's rights, which require more than the existed local regulation. The local government with Minister of Agrarian Affairs/Head of National Land Agency and Ministry of Environment and Forestry must elaborate for regulation and legal policies, the government action especially the rights of land. For example Ministry Decree by The Ministry of Environment and Forestry for designation of "adat" forest area; The register for "ulayat" or communal land based on Regulation of Minister of Agrarian Affairs/Head of National Land Agency Number 5 of 1999, which was replaced by Regulation of the Minister of Agrarian and Spatial Planning/Head of National Land Agency Number 10 of 2016, which was contrary by law with Government Regulation Number 24 of 2007 about Land Register. Keywords: Recognition; Indigenous Peoples; Local Regulation; Land Register.
\end{abstract}

\footnotetext{
Pengakuanterhadapmasyarakatadatsangatpenting.Pengakuantersebutakanmendorong keberadaan masyarakat adat agar dilindungi oleh undang-undang serta perlindungan hak atas tanah mereka. Jurnal ini akan menganalisis proses awal pengakuan, praktik dan implementasi pengakuan dan pasca munculnya perda tentang pengakuan masyarakat adat. Metode penelitian jurnal adalah penelitian hukum normatif dengan pendekatan patung dan pendekatan konseptual. Penulisan jurnal menggunakan interpretasi gramatikal dan interpretasi sistematis. Hasil penelitian dalam jurnal tersebut merupakan upaya perlindungan dan pemenuhan hak-hak masyarakat adat yang membutuhkan lebih dari peraturan daerah yang ada. Pemerintah daerah bersama Menteri Agraria / Kepala Badan Pertanahan Nasional dan Kementerian Lingkungan Hidup dan Kehutanan harus merinci peraturan dan kebijakan hukum, tindakan pemerintah khususnya hak atas tanah. Misalnya Keputusan Menteri Lingkungan Hidup dan Kehutanan tentang penetapan kawasan hutan "adat"; Pendaftaran ulayat atau tanah ulayat berdasarkan Peraturan Menteri Agraria / Kepala Badan Pertanahan Nasional Nomor 5 Tahun 1999, yang diganti dengan Peraturan Menteri Agraria dan Tata Ruang / Kepala Badan Pertanahan Nasional Nomor 10 Tahun 2016, yang bertentangan dengan Undang-undang dengan Peraturan Pemerintah Nomor 24 Tahun 2007 tentang Pendaftaran Tanah..

Kata Kunci: Pengakuan; Masyarakat Hukum Adat; Peraturan Daerah; Pendaftaran Hak Atas Tanah.
}

Abstrak 


\section{Pendahuluan}

Tanah bagi masyarakat hukum adat bukan hanya sekedar tanah, tetapi juga bagian dari identitas mereka, tempat asal usul mereka berasal, tempat mereka menjalankan kegiatan ritual kepercayaan, Tanah juga memiliki nilai sosial dan kultural, selain nilai ekonomi. Bagi masyarakat hukum adat, mereka tidak akan melepaskan (menjual) tanahnya kepada pihak diluar kelompok masyarakat hukum adat (orang asing). Di Papua misalnya, tanah dianggap "mama, dan tidak diperjualbelikan", maka jika ada seorang pendatang yang ingin mendirikan rumah tempat tinggal atau bangunan lain diatas tanah ulayat suku tertentu, maka si pendatang tersebut harus memperoleh persetujuan dari kepala suku dan anggota keluarga dari suku tersebut, serta membayar sejumlah uang yang dianggap sebagai "pengganti" atau dalam hukum agraria dikenal istilah "recognitie" , yang besarannya ditetapkan berdasarkan keputusan bersama dari masyarakat hukum adat. Konflik terjadi jika pihak luar masuk dan menempati wilayah masyarakat hukum adat tanpa sepengetahuannya. Atau dalam beberapa kasus, masyarakat hukum adat tidak dapat masuk kedalam wilayah mereka yang dipandang sakral karena telah di klaim milik orang lain atau perusahaan.

Persoalan konflik agraria bukan hanya tentang perluasan lahan atau penerbitan izin baru perkebunan yang melanggar hak-hak masyarakat atas tanah, tetapi juga persoalan tumpang tindih hak atas tanah dengan perusahaan swasta maupun perusahaan milik negara. ${ }^{1}$ Komnas HAM mencatat sepanjang 2017 terdapat 269 kasus, yang terdiri dari konflik lahan (104 kasus), perkebunan (39 kasus), innfrastruktur (32 kasus), pertambangan (24 kasus), kehutanan (24 kasus), lingkungan (19 kasus) dan penegakan hukum (23 kasus). ${ }^{2}$ pada kurun waktu 2012-2014, kategori agraria merupakan berkas terbanyak kedua yang diterima oleh Komnas HAM setelah kategori kepolisian. Sebagai catatan pada tahun 2012 terdapat 1213 berkas, tahun 2013 terdapat 1123 berkas, dan pada tahun 2014

\footnotetext{
${ }^{1}$ Masa Depan Reforma Agraria Melampaui Tahun Politik, Catatan Akhir Tahun 2018 Konsorsium Pembaharuan Agraria (KPA 2018).[20].

2 Laporan Tahunan Komisi Nasional Hak Asasi Manusia 2018; (KOMNAS HAM 2018).[85].
} 
terdapat 1134 berkas. ${ }^{3}$

Persoalan saling klaim yang berujung pada konflik, biasanya terjadi karena pihak perusahaan telah memperoleh ijin lokasi atas usahanya, tetapi pihak masyarakat hukum adat merasa bahwa tanah-tanah tersebut merupakan miliknya. Mereka tidak mengetahui bahwa tanah-tanah tersebut masuk kedalam kawasan yang ijinnya dimiliki oleh perusahaan. Masyarakat hukum adat kesulitan jika diminta untuk membuktikan bahwa tanah-tanah tersebut adalah milik mereka. Komnas HAM juga mencatat bahwa salah satu persoalan konflik agraria tersebut adalah tidak atau belum adanya pengakuan sebagai masyarakat hukum adat yang berimplikasi pada tidak jelasnya atau tidak pastinya status mereka secara hukum. ${ }^{4}$

Tujuan pendaftaran tanah adalah memberikan kepastian hukum dan perlindungan kepada pemegang hak atas suatu bidang tanah, satuan rumah susun dan hak-hak lainnya yang terdaftar agar dengan mudah dapat membuktikan dirinya sebagai pemegang hak yang bersangkutan, sebagaimana diatur dalam pasal 3 Peraturan Pemerintah No. 24 tahun 1997 tentang Pendaftaran Tanah. Pasal 32 menyebutkan bahwa sertipikat merupakan surat tanda bukti hak yang berlaku sebagai alat pembuktian yang kuat. Tanah ulayat bukanlah objek pendaftaran tanah berdasarkan peraturan pemerintah tersebut. Atas dasar tersebut, tanah hak ulayat yang dikuasai oleh masyarakat hukum adat bukanlah objek pendaftaran tanah, sehingga masyarakat hukum adat akan kesulitan dalam membuktikan bahwa tanah tersebut adalah miliknya. Oleh karena itu, memperoleh pengakuan akan keberadaan mereka sebagai masyarakat hukum adat merupakan sesuatu yang sangat penting. Pengakuan terhadap keberadaan masyarakat hukum adat akan memberikan kepastian dan perlindungan hukum yang jelas terhadap mereka. Perlindungan tersebut termasuk juga perlindungan terhadap hak-haknya, salah satunya adalah hak atas tanah.

\footnotetext{
${ }^{3}$ Komnas HAM; Inkuiri Nasional Komnas HAM-Hak Masyarakat Hukum Adat atas Wilayahnya di Kawasan Hutan; (Komnas HAM 2016).[1].

4 ibid.[56].
} 
Undang-Undang Nomor 5 Tahun 1960 tentang Peraturan Dasar PokokPokok Agraria pasal 3 menyebutkan mengenai pengakuan masyarakat hukum adat, hanya saja tidak diatur secara mendalam mengenai bagaimana dan bentuk dari pengakuan tersebut. Pengakuan masyarakat hukum adat juga diatur dalam Undang-Undang Nomor. 23 Tahun 2014 tentang Pemerintah Daerah yang kemudian diubah dengan Undang-Undang Nomor 9 tahun 2015 tentang Perubahan Kedua atas Undang-Undang Nomor 23 tahun 2014 tentang Pemerintahan Daerah, serta Peraturan Menteri Dalam Negeri Nomor 52 tahun 2014 tentang Pedoman Pengakuan dan Perlindungan Masyarakat Hukum Adat. Kedua ketentuan hukum terakhir menjelaskan bahwa pengakuan masyarakat hukum adat menjadi tanggung jawab dari pemerintah daerah, dengan produk hukumnya adalah Peraturan Daerah tentang Pengakuan Masyarakat.

Saat ini terdapat kurang lebih 84 (delapan puluh empat) ${ }^{5}$ peraturan daerah tentang Pengakuan Masyarakat Hukum Adat. Peraturan-peraturan daerah tersebut, sebagian besar mengatur mengenai identitas atau asal usul kelompok masyarakat hukum adat, batas-batas wilayah, hukum dan kelembagaan adat, tanah ulayat atau tanah komunal beserta dengan pemanfaatanya serta halhal lainnya yang dipandang perlu. Faktanya, proses masyarakat hukum adat memperoleh pengakuan hingga terbitnya peraturan daerah tentang pengakuan tersebut sangat panjang. Menurut Peraturan Menteri Dalam Negeri No. 52 tahun 2014 tentang Pedoman Pengakuan dan Perlindungan Masyarakat Hukum Adat menyebutkan terdapat 3 (tiga) tahapan besar, yaitu Identifikasi, Verifikasi dan Validasi, Penetapan. Masing-masing tahapan tersebut dalam prakteknya sangat panjang dan memiliki hambatannya masing-masing. Tahap Identifikasi misalnya, masyarakat hukum adat yang bersangkutan bersama dengan panitia yang telah ditunjuk harus dapat mengidentifikasi mengenai sejarah, wilayah adat, hukum adat serta harta kekayaan yang dimilikinya. Faktanya dalam mengidentifikasi hal-

${ }^{5}$ Berdasarkan apa yang telah disampaikan oleh Aliansi Masyarakat Hukum Adat (AMAN) dalam Diskusi Pararel "Konstekstualisasi dan Perlindungan Masyarakat Hukum Adat" dalam acara Festival Hak Asasi Manusia ke 6 tahun 2019, Jember 19-21 November 2019. 
hal sebagaimana yang telah disebutkan, masyarakat hukum adat mengandalkan kepada sejarah lisan yang diturunkan secara turun temurun, dan batas-batas alam untuk menandai batas wilayahnya, yang seringkali sudah hilang karena faktor alam. Fakta lainnya adalah beberapa peraturan daerah yang sudah muncul, merupakan upaya dan dorongan dari masyarakat hukum adat untuk segera memperoleh pengakuan, karena mereka diperhadapkan dengan konflik agraria, khusunya saling klaim atas tanah wilayah adatnya. Seperti yang terjadi di masyarakat hukum adat Mentawai dan Masyarakat Hukum Adat Kajang.

Peraturan daerah tentang pengakuan bukanlah tujuan akhir dari usaha memberikan perlindungan dan pemenuhan hak masyarakat hukum adat, tetapi langkah awal yang harus diikuti dengan langkah-langkah konkret lainnya. Pasca muculnya peraturan daerah tentang pengakuan masyarakat hukum adat perlu dilanjutkan dengan langkah-langkah hukum lainnya. Seperti program-program perlindungan dan pemenuhan hak bagi masyarakat hukum adat (seperti akses pendidikan, akses kesehatan, akses ekonomi, hak atas identitasnya, jaminan atas agama dan kepercayaannya, pengakuan dan perlindungan terhadap tanah dan batasbatas wilayah, serta hak-hak lainnya), serta memfasilitasi konflik yang ada antara masyarakat hukum adat dengan perusahaan dengan menjamin hak-hak mereka. Sehingga hak-hak masyarakat hukum adat benar-benar terlindungi dan terpenuhi.

Jurnal ini akan menganalisa mengenai proses awal pengakuan, praktek dan penerapan dari pengakuan, serta pasca munculnya peraturan daerah tentang pengakuan masyarakat hukum adat. Analisa jurnal ini akan melihat mengenai apakah peraturan daerah yang telah dikeluarkan tersebut benar-benar dapat memberikan perlindungan dan pemenuhan terhadap hak-hak dari masyarakat hukum adat.

\section{Metode Penelitian}

Metode penelitian yang digunakan dalam jurnal ini adalah penelitian hukum normatif, karena akan mengkaji dan menganalisa hubungan berbagai peraturan perundang-undangan dan ketentuan hukum lainnya terkait dengan 
pengakuan masyarakat hukum adat serta perlindungan terhadap tanah masyarakat hukum adat.

Pendekatan pertama yang digunakan adalah pendekatan peraturan perundang-undangan (Statute Approach), dilakukan dengan menelaah semua undang-undang dan regulasi yang ada sangkut pautnya dengan isu hukum yang sedang dibahas. ${ }^{6}$ Peraturan perundang-undangan yang dimaksud terkait dengan masyarakat hukum adat, mengenai tanah ulayat, dan pengakuan masyarakat hukum adat. Pendekatan kedua yang digunakan adalah pendekatan konseptual (Conseptual Approach), pendekatan ini berpijak pada pandangan dan doktrin yang berkembang dalam ilmu hukum untuk menemukan ide-ide yang melahirkan pengertian hukum, konsep hukum dan asas-asas hukum yang relevan dengan isu hukum yang dihadapi.

Sumber bahan hukum yang digunakan adalah sumber hukum primer dan sumber hukum sekunder. Bahan hukum primer yang akan digunakan dalam penulisan jurnal adalah peraturan perundang-undangan yang terkait dengan pengakuan masyarakat hukum adat. Bahan hukum sekunder dalam penulisan jurnal ini menggunaan bahan hukum yang berasal dari literatur-literatur, jurnal hukum, kamus hukum, hasil penelitian, jurnal, disertasi yang terkait dengan pengakuan masyarakat hukum adat.

Pengumpulan bahan hukum dari jurnal ini dilakukan melalui studi pustaka dengan inventarisasi, klasifikasi dan sistematisasi. Inventarisasi dilakukan dengan mengumpulkan bahan-bahan hukum terkait pengakuan masyarakat hukum adat. Kemudian diklasifikasikan sesuai dengan rumusan masalah yang tersebut diatas. Untuk mempermudah dan memahami bahan hukum tersebut maka dipelajari dengan cara sistematik.

Penulisan jurnal ini menggunakan interpretasi gramatical (bahasa) dan interpretasi sistematis. Interpretasi gramatical (bahasa) adalah cara penafsiran atau penjelasan yang paling sederhana untuk mengetahui makna ketentuan

${ }^{6}$ Peter Mahmud Marzuki, Penelitian Hukum (Kencana Prenadamedia Group 2009).[35]. 
perundang-undangan dengan menguraikannya menurut bahasa, susun kata atau bunyinya. ${ }^{7}$ Interpretasi sistematis adalah menafsirkan undang-undang dengan menghubungkannya dengan peraturan hukum lainnya atau dengan sistem hukum. Sehingga dalam interpretasi sistematis, hukum dipandang sebagai suatu sistem peraturan. Interpretasi gramatical (bahasa) dalam jurnal ini akan digunakan dengan cara memahami makna ketentuan hukum yang ada dalam peraturan perundang-undangan yang terkait dengan pengakuan masyarakat hukum adat. Baik yang terdapat di dalam Undang-Undang Pokok Agraria No. 5 Tahun 1960, Undang-Undang No. 27 Tahun 2007 tentang Pengelolaan Wilayah Pesisir dan Pulau Pulau Kecil, Permendagri No. 52 Tahun 2014 Tentang Pedoman Pengakuan dan Perlindungan Masyarakat Hukum Adat. Sedangkan Interpretasi Sistematis dalam penulisan jurnal ini akan digunakan dengan menghubungkan antara satu peraturan perundang-undangan dengan peraturan perundang-undangan lainnya.

\section{Pengakuan Masyarakat Hukum Adat}

Pengakuan (erkening) secara terminologi diterjemahan menjadi proses, cara perbuatan mengakui. Menurut Hans Kelsen, ${ }^{8}$ terminologi pengakuan ada kaitanya dengan keberadaan suatu negara, terdapat dua tindakan terkait dengan pengakuan, yaitu tindakan politik dan tindakan hukum. Tindakan politik mengakui suatu negara (keberadaan masyarakat hukum adat) berarti negara mengakui kehendak untuk mengadakan hubungan-hubungan politik dan hubungan-hubungan lain dengan masyarakat yang diakuinya. Tindakan hukum adalah prosedur yang dikemukakan oleh hukum internasional untuk menetapkan fakta negara (masyarakat adat) dalam suatu kasus konkret. ${ }^{9}$

Merujuk kepada pendapat Hans Kelsen tersebut, maka pengakuan terhadap masyarakat hukum adat atas tanah bermakna bahwa pengakuan dari negara/

7 Sudikno Mertokusumo dan A.Pitlo, Bab-Bab Tentang Penemuan Hukum, (PT. Citra Karya Bakti 1993).[13].

8 Hans Kelsen, General Theory of Law and State (Rimdi Press).[222] sebagaimana dikutip dalam Husen Alting; Penguasaan Tanah Masyarakat Hukum Adat (Suatu Kajian terhadap Masyarakat Hukum Adat Ternate) Vo. 11 No. 1 Tahun 2011 Jurnal Dinamika Hukum.[89].

9 ibid. 
pemerintah baik secara politik maupun hukum, melalui pengaturan hak dan kewajiban dalam peraturan perundang-undangan dan ketentuan hukum lainnya merupakan bentuk pemenuhan tanggung jawab negara/pemerintah untuk memberikan perlindungan terhadap hak-hak masyarakat hukum adat. Pengakuan menunjukkan bahwa negara/pemerintah telah mengakui, menyatakan sah/benar atau menyatakan masyarakat hukum adat berhak atas sumberdaya alam yang dimiliki dan mewajibkan pemerintah untuk melindungi hak-hak tersebut dari ancaman dan gangguan pihak lain.

Mengutip pendapat Maria S.W Soemardjono, bahwa: ${ }^{10}$

“Perda/Perkada/SK Kepala Daerah itu tidak menjadikan hak ulayat itu ada (konstitutif), tetap hanya menyatakan (deklaratoir) bahwa hak ulayat itu sudah ada walaupun tanpa melalui Perda/Perkada/Keputusan Kepala Daerah. Keputusan Kepala Daerah bagi hak ulayat yang beraspek publik dan privat, atau sertifikat tanah milik bersama MHA bagi hak ulayat yang beraspek privat belaka itu merupakan penuntasan proses administrasi pengakuan MHA".

Pengakuan declatoir sebagaimana yang dinyatakan oleh Maria S.W Soemardjono, dapat dimaknai bahwa dengan adanya pengakuan dari pemerintah daerah tersebut hanya menegaskan kembali dan menyatakan bahwa masyarakat hukum adat yang sudah ada sebelumnya tersebut diakui keberadaanya oleh negara. Karena pada kenyataanya, masyarakat hukum adat memang sudah ada jauh sebelum munculnya berbagai peraturan-peraturan daerah tersebut. UndangUndang Pokok Agraria No. 5 Tahun 1960 menjadikan hukum adat sebagai dasar pembentukannya.

Berbagai peraturan perundang-undangan lainnya, juga menyebutkan mengenai pengakuan masyarakat hukum adat. Undang-Undang Pokok Agraria No. 5 tahun 1960 (UUPA) pasal 3 yang menyebutkan “...pelaksanaan hak ulayat dan hak-hak serupa itu dari masyarakat-masyarakat hukum adat, sepanjang menurut kenyataanya masih ada, harus sedemikian rupa sehingga sesuai dengan kepentingan nasional dan Negara,...". Frasa "menurut kenyataanya masih ada"

${ }^{10}$ Maria SW Sumardjono, Agenda yang Belum Selesai-Refleksi atas Berbagai Kebijakan Pertanahan, (Fakultas Hukum Universitas Gadjah Mada 2020).[5]. 
dapat dimaknai bahwa eksistensi dari masyarakat hukum adat harus dibuktikan keberadaanya baru kemudian pelaksanaan hak ulayat dapat dilakukan. Pembuktiaan akan keberadaan masyarakat hukum adat tersebut dilakukan dengan cara pengakuan oleh negara melalui pemerintah daerah. UUPA sendiri tetapi tidak mengatur lebih jelas mengenai bentuk dari pengakuan tersebut. Sedangkan ketentuan hukum mengenai pengakuan harus melalui sebuah peraturan daerah dapat ditemukan dalam MK No. 35/PUU-X/2012, Peraturan Menteri Agraria dan Tata Ruang/Kepala Badan Pertanahan Nasional Nomor 5 tahun 1999 tentang Pedoman Penyelesaian Masalah Hak Ulayat Masyarakat Hukum Adat tersebut dicabut dan dinyatakan tidak berlaku, serta digantikan dengan Peraturan Menteri Agraria dan Tata Ruang/Kepala Badan Pertanahan Nasional Nomor 9 tahun 2015 tentang Tata Cara Penetapan Hak Komunal dan Tanah Masyarakat Hukum Adat dan Masyarakat yang Berada dalam Kawasan Tertentu, kemudian diganti dengan Peraturan Menteri Agraria dan Tata Ruang/Kepala Badan Pertanahan Nasional Republik Indonesia Nomor 10 tahun 2016 tentang Tata Cara Penetapan Hak Komunal atas Tanah Masyarakat Hukum Adat dan Masyarakat yang Berada dalam Kawasan Tertentu

Pengakuan akan keberadaan masyarakat hukum adat merupakan kewenangan dari kepala daerah sebagaimana diatur dalam Undang-Undang No. 32 tahun 2014 tentang Pemerintah Daerah yang menggantikan Undang-Undang Nomor 32 tahun 2004. Pengakuan masyarakat hukum merupakan bagian dari pembagian urusan pemerintahan konkuren wajib yang tidak berkaitan dengan pelayanan dasar, terutama masuk kedalam urusan yang berkaitan dengan urusan bidang Lingkungan Hidup ${ }^{11}$ dengan sub bidang "Pengakuan Keberadaan Masyarakat Hukum Adat (MHA), kearifan lokal dan hak MHA yang terkait dengan PPLH", sedangkan tentang tanah ulayat menjadi bagian dari urusan pemerintahan bidang pertanahan dengan sub urusan tentang “Tanah Ulayat". ${ }^{12}$

11 Matriks Pembagian Urusan Pemerintahan Konkuren Antara Pemerintahan Pusat dan Daerah Provinsi dan Daerah Kabupaten/Kota; HurufK Nomor 7, sebagaimana diatur Lampiran Undang-Undang No. 23 Tahun 2014 tentang Pemerintahan Daerah.

12 ibid. 
Peraturan Menteri Dalam Negeri No. 52 tahun 2014 tentang Pedoman Pengakuan dan Perlindungan Masyarakat Hukum Adat, yang merupakan aturan pelaksana dari Undang-Undang No. 23 tahun 2014 tentang Pemerintah Daerah. Peraturan Menteri Dalam Negeri No. 52 tahun 2014 pasal 4 menyebutkan terdapat 3 tahapan besar yang harus dilalui oleh masyarakat hukum adat hingga Peraturan Daerah tentang pengakuan masyarakat hukum adat terbit. Tahapan tersebut adalah:

1. Identifikasi Masyarakat Hukum Adat;

2. Verifikasi dan Validasi;

3. Penetapan Masyarakat Hukum Adat.

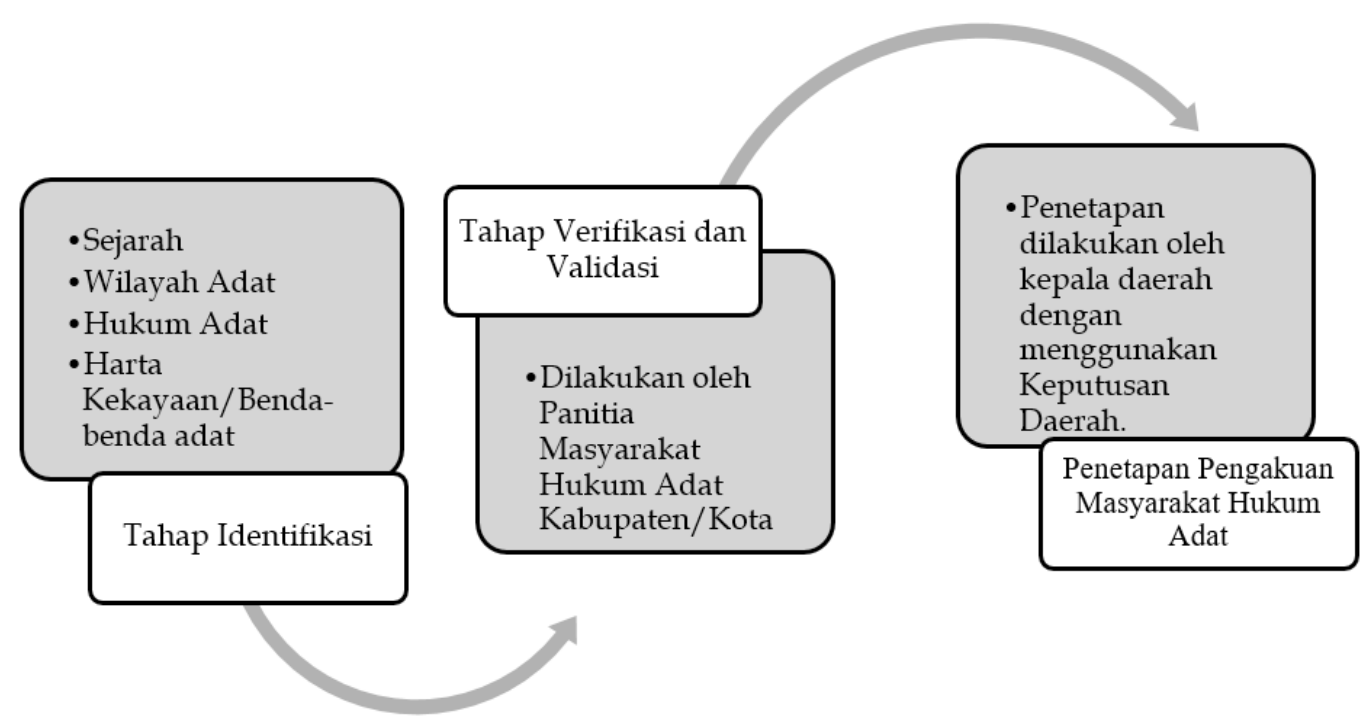

Figure 1. Berdasarkan Peraturan Menteri Agraria Nomor 52 tahun 2014 tentang Pedoman dan Pengakuan Masyarakat Hukum Adat

Tahapan Identifikasi, merupakan tahapan awal yang cukup penting. Dalam tahapan ini, masyarakat hukum adat bersama dengan camat diminta untuk mengidentifikasi mengenai sejarah, wilayah adat, hukum adat, harta kekayaaan/ Benda-Benda Adat. Permendagri tersebut tidak menjelaskan secara mendetail mengenai tata cara melalukan tahapan identifikasi tersebut. Praktiknya, tahapan identifikasi ini justru memakan waktu yang cukup lama. Untuk mengidentifikasi sejarah, hukum adat serta harta kekayaan misalnya, penelusuran mengandalkan ingatan kolektif yang disampaikan secara lisan turun temurun, sedangkan untuk 
hukum adat merujuk kepada kebiasaan-kebiasaan dan sanksi adat yang ada di masyarakat hukum adat tersebut. Identifikasi wilayah, selain mengandalkan ingatan kolektif juga menggunakan bentuk pemetaan partispatif (community mapping atau participatory mapping). Pemetaan partisipatif merupakan pemetaan yang menghasilkan peta yang dapat menunjukkan batas wilayah adat (teritori), pola penggunaan lahan dan sumber daya alam, pola hubungan social serta pola hubungan budaya (dan juga spiritual) komunitas masyarakat hukum adat. Pemetaan partisipatif adalah suatu alat yang dipercaya dapat digunakan untuk mengakomodasi kepentingan masyarakat dan melakukan konter terhadap kebijakan pengelolaan hutan oleh negara atau pihak luar. ${ }^{13}$

Kendala-kendala yang muncul dalam tahapan ini, antara lain informasi awal hanya mengandalkan kepada ingatan kolektif dari masyarakat hukum adat yang bersangkutan, batas-batas alam yang sudah mulai hilang, konflik internal di dalam masyarakat hukum adat seperti siapa yang berhak mewakili masyarakat hukum adat ketika menghadiri diskusi-diskusi dengan panitia atau gugus tugas yang ditunjuk.

Selain kendala-kendala yang telah disampaikan diatas, faktor anggaran juga memiliki peran yang sangat besar dalam pengakuan masyarakat hukum adat melalui peraturan daerah. Anggaran untuk proses diskusi di kalangan internal masyarakat hukum adat, diskusi dan komunikasi antara pemerintah daerah, para tokoh serta masyarakat hukum adat sendiri, proses pemetaan, verifikasi, validasi hingga pembahasan rancangan peraturan daerah hingga menjadi sebuah peraturan daerah, membutuhkan biaya yang cukup besar. Selain anggaran, masih ada faktor penting yang berpengaruh terhadap munculnya peraturan daerah pengakuan seperti peta politik dan kepentingan di wilayah tersebut, prioritas daerah serta kemauan dari para pemimpin daerah.

Permendagri tidak menyebutkan berapa total jangka waktu yang dibutuhkan oleh suatu masyarakat hukum adat dari proses awal hingga memperoleh

13 Peluso, "Seeing Property in Land Use; Local Territorialization in West Kalimantan Indonesia, 2005, sebagaimana dikutip dalam Berebut Hutan Siberut - Orang Mentawi, Kekuasaan dan Politik Ekologi (PT Gramedia 2007).[325]. 
pengakuan melalui peraturan daerah. Proses pengakuan masyarakat hukum adat dalam prakteknya, bisa berlangsung cukup lama, berbulan-bulan hingga bertahuntahun. Seperti yang dialami oleh Masyarakat Hukum Adat Mentawai, Masyarakat Hukum Adat Ammatoa Kajang, Masyarakat Hukum Adat Pandumaan Sipituhuta, serta masyarakat hukum adat lainnya.

Diskusi tentang perlunya pengakuan bagi masyarakat hukum adat Mentawai telah muncul pada era-90an. Dilatarbelakangi oleh berbagai konflik antara masyarakat hukum adat Mentawai dengan perusahaan-perusahaan kayu yang sudah muncul sejak tahun 1970an dan $1980^{14}$ tetapi konflik atau protes terdengar sejak dekade 1990-an. ${ }^{15}$ Sekitar tahun 2006, pembahasan mengenai pengakuan mulai intens dilakukan di kalangan masyarakat hukum adat dan pengakuan keberadaan masyarakat hukum adat Mentawai baru diakui secara hukum dengan terbitnya Peraturan Daerah Kabupaten Mentawai No. 11 Tahun 2017 tentang Pengakuan dan Perlindungan Uma sebagai Kesatuan Masyarakat Hukum Adat di Kabupaten Kepulauan Mentawai.

Masyarakat hukum Adat Ammatoa Kajang telah memiliki konflik yang lama dengan PT. Lonsum, yang berawal dengan pemberian ijin konsesi kepada PT. Lonsum oleh pemerintah daerah Kabupaten Bulukumba. Konflik tersebut terjadi karena wilayah masyarakat hukum adat dimasukkan ke dalam wilayah hutan negara dan akhirnya menjadi bagian dari wilayah konsesi PT. Lonsum tersebut. Pada tahun 2008, pemerintah daerah Kabupaten Bulukumba pernah Menyusun Rancangan Peraturan Daerah tentang Penetapan Hutan Adat Kajang, tetapi pembahasan tersebut tidak dilanjutkan lagi oleh DPRD dengan alasan penetapan hutan adat belum memiliki dasar hukum yang kuat. Pasca putusan MK No. 35/PUU-X/2012 telah mendorong pemerintah daerah kabupaten Bulukumba bersama dengan beberapa CSO seperti Aliansi Masyarakat Hukum Adat Nusantara (AMAN) Sulawesi Selatan dan Centre

\footnotetext{
${ }_{14}$ Darmanto, Berebut Hutan Siberut- Orang Mentawai, Kekuasaan dan Politik Ekologi (Kelompok Populer Gramedia 2012).[161].

15 ibid.[160].
} 
for International Forestry Research (CIFOR) kembali mendikusikan mengenai pengakuan masyarakat hukum adat. SK Bupati Bulukumba No. 760/ VII/2013 tentang Pembentukan Tim Penyusunan Rencana Peraturan Daerah terkait Pengakuan Masyarakat Hukum Adat di Kabupaten Bulukumba. Tim beranggotakan Tim tersebut beranggotakan Kepala Dinas Pariwisata, Kepala Bagian Hukum Setda Kabupaten Bulukumba, kepala Dinas Kehutanan dan Perkebunan, Kepala BPN, Camat Kajang, AMAN, CIFOR, AGFOR, Balang Institute, serta Perwakilan Masyarakat Hukum Adat Kajang. Tim ini melakukan penyusunan naskah akademik, rancangan peraturan daerah, pemetaan partisipatif, melakukan penelitian, serta diskusi-diskusi penguatan kapasitas. Baru pada tahun 2015, Peraturan Daerah Kabupaten Bulukumba No. 9 tahun 2015 tentang Pengukuhan, Pengakuan dan Perlindungan Hak-Hak Masyarakat Adat Ammatoa Kajang disahkan.

Masyarakat Hukum Adat Pandumaan dan Sipihuta yang berada di Kecamatan Pollung Kabupaten Humbang Hasundutan Provinsi Sumatera Utara memiliki konflik dengan PT. Toba Pulp Lestari (TPL). Masyarakat Hukum Adat Pandumaan dan Sipihuta hidup dari pertanian padi, kebun kopi skala kecil dan mengolah kemenyan dari Hutan Kemenyan yang berada di wilayah adatnya. Pohon kemenyan dianggap penting karena dianggap sumber penghidupan tapi juga dianggap memiliki nilai sakral dan magis sehingga tidak boleh ditebang. Konflik yang bermula sejak tahun 2009 , ketika PT. Toba Pulp Lestari melakukan penebangan secara besar-besaran terhadap pohon kemenyan. Pada tahun 2016, Kementerian Lingkungan Hidup dan Kehutanan mengeluarkan hutan adat Pandumaan Sipituhuta seluas 5.000 (lima ribu) hektar dari konsesi PT. Toba Pulp Lestari. ${ }^{16}$ Pada tahun 2019, Bupati Humbang Hasundutan Provinsi Sumatera Utara mengeluarkan Peraturan Daerah Kabupaten Humbang Hasundutan Nomor 3 tahun 2019 tentang Pengakuan dan Perlindungan Masyarakat Hukum Adat Pandumaan Sipituhuta.

16 www.mongabay.co.id "Perda Perlindungan Masyarakat Adat Pandumaan Sipituhuta Ketok 
Ketiga contoh kemunculan peraturan daerah diatas, memiliki latar belakang konflik agraria yang berkepanjangan. Masyarakat hukum adat kehilangan hak atas tanah miliknya, dan mereka berusaha mempertahankan tanah miliknya kembali. Memperoleh pengakuan terhadap keberadaan mereka merupakan salah satu cara untuk dapat membuktikan eksistensi mereka sebagai masyarakat hukum adat. Pengakuan tersebut diharapkan dapat memberikan perlindungan dan pemenuhan terhadap hak-hak mereka sebagai masyarakat hukum adat, termasuk juga perlindungan terhadap tanah miliknya. Proses terbitnya peraturan daerah tentang pengakuan masyarakat hukum adat mengalami proses yang panjang sebelumnya dan memakan waktu bertahun-tahun.

Peraturan daerah tentang pengakuan masyarakat hukum adat tersebut bukanlah tujuan akhir dalam memperoleh perlindungan terhadap hak-hak masyarakat hukum adat tetapi awal dari berbagai upaya pemenuhan perlindungan terhadap hak-hak masyarakat hukum adat. Peraturan-peraturan daerah pengakuan masyarakat hukum adat tersebut perlu di terapkan dengan baik. Misalnya penetapan Kawasan hutan adat berdasarkan Peraturan Menteri Lingkungan Hidup dan Kehutanan No. P.31/Menlhk-Setjen/2015, program-program pemberdayaan masyarakat dan askses-akses pemenuhan hak, status hukum terhadap tanah-tanah masyarakat hukum adat, serta upaya-upaya penyelesaian konflik.

\section{Perlindungan Hukum Pasca Pengakuan Masyarakat Hukum Adat}

Pasca dikeluarkannya peraturan daerah tentang pengakuan masyarakat hukum adat, seharusnya diiikuti dengan langkah-langkah kebijakan lainnya. Seperti:

1. Penetapan Kawasan Hutan

Berdasarkan Peraturan Menteri Lingkungan Hidup dan Kehutanan No. P.31/Menlhk-Setjen/2015 tentang Hutan Hak, dalam pasal 4 menyebutkan bahwa perlu ada pengajuan permohonan penetapan kawasan hutan kepada Menteri. Masyarakat hukum adat yang telah memperoleh pengakuan melalui peraturan daerah dapat mengajukan permohonan penetapan Kawasan 
Hutan Adat kepada kepada Menteri Lingkungan Hidup dan Kehutanan. Setelah melalui beberapa tahap verifikasi dan ajudikasi, kemudian Menteri Lingkungan Hidup dan Kehutanan akan mengeluarkan penetapan kawasan hutan adat di wilayah masyarakat hukum adat.

Peraturan Menteri Lingkungan Hidup dan Kehutanan No. P.31/ Menlhk-Setjen/2015 tentang Hutan Hak pasal 4 ayat 3 menyebutkan bahwa “berdasarkan permohonan sebagaimana dimaksud dalam ayat (1) dan ayat (2) Menteri melakukan verifikasi dan validasi". Frasa verifikasi dan validasi ini dalam prakteknya menjadi kendala, karena membutuhkan sumber daya yang cukup besar, baik anggaran dan sumber daya di lapangan.

Masyarakat hukum adat Ammatoa Kajang misalnya, pasca munculnya Peraturan Daerah Kabupaten Bulukumba No. 9 Tahun 2015 tentang Pengukuhan, Pengakuan dan Perlindungan Hak-Hak Masyarakat Adat Ammatoa Kajang, mereka mengajukan mengajukan permohonan penetapan hutan adat Ammatoa Kajang seluas + 313,99 ha kepada Kementerian Lingkungan Hidup dan Kehutanan. Melalui Keputusan Menteri Lingkungan Hidup dan Kehutanan Republik Indonesia Nomor:SK.6747/MENLHK.PSKL/ KUM.1/12/2016 tentang Penetapan Hutan Adat Ammatoa Kajang Seluas + 313,99 (tiga ratus tiga belas dan sembilan puluh sembilan perseratus) hektar di kecamatan Kajang Kabupaten Bulukumba Provinsi Sulawesi Selatan, telah memiliki dasar hukum yang kuat masuk kedalam wilayah masyarakat hukum adat Kajang.

2. Pendaftaran tanah ulayat dan/atau tanah hak komunal

Pencabutan Peraturan Menteri Negara Agraria/Kepala Badan Pertanahan Nasional Nomor 5 tahun 1999 yang mengatur tentang hak ulayat kemudian diganti dengan Peraturan Menteri Agraria dan Tata Ruang/Kepala Badan Pertanahan Nasional Nomor 10 tahun 2016 yang mengatur mengenai hak komunal, telah memberikan persoalan baru. Persoalan pertama adalah definisi hak ulayat dalam Peraturan Menteri Negara Agraria/Kepala Badan Pertanahan Nasional Nomor 5 tahun 1999 dengan definisi hak komunal 
yang diatur dalam Peraturan Menteri Agraria dan Tata Ruang/Kepala Badan Pertanahan Nasional Nomor 10 tahun 2016. Persoalan kedua adalah mengenai frasa "pendaftaran tanah.." yang terdapat dalam Peraturan Menteri Negara Agraria / Kepala Badan Pertanahan Nasional Nomor 5 tahun 1999 maupun Peraturan Menteri Agraria dan Tata Ruang/Kepala Badan Pertanahan Nasional Nomor 10 tahun 2016.

Pertama, definisi hak ulayat menurut Peraturan Menteri Negara Agraria/Kepala Badan Pertanahan Nasional Nomor 5 tahun 1999 adalah kewenangan menurut hukum adat dipunyai oleh masyarakat hukum adat tertentu atas wilayah tertentu yang merupakan lingkungan para warganya untuk mengambil manfaat dari sumber daya alam, termasuk tanah, dalam wilayah tersebut, bagi kelangsungan hidup dan kehidupannya, yang timbul dari hubungan secara lahiriah, dan batiniah turun temurun dan tidak terputus antara masyarakat hukum adat tersebut dengan wilayah yang bersangkutan. Definisi hak komunal menurut Peraturan Menteri Agraria dan Tata Ruang/ Kepala Badan Pertanahan Nasional Nomor 10 tahun 2016 adalah hak milik bersama atas tanah suatu masyarakat hukum adat, atau hak milik bersama atas tanah yang diberikan kepada masyarakat yang berada dalam Kawasan Tertentu. Walaupun kedua hak tersebut sama-sama hak yang dimiliki oleh masyarakat hukum adat serta dapat diusahakan dengan tujuan kesejahteraan masyarakatnya tetapi mememiliki karakter yang berbeda. Pendefinisian hak komunal tidak dikenal dalam ketentuan hukum sebelumnya, selain itu definisi hak komunal ingin menjangkau hak-hak lain secara luas (seperti hak yasan, hak atas druwe, pesini, tanah partikelir maupun hak-hak lainnya yang serupa) serta hak-hak masyarakat hukum adat di wilayah tertentu yang dapat dimaknai sebagai Kawasan hutan.

Pencabutan dan dinyatakan tidak berlakunya Peraturan Menteri Negara Agraria/Kepala Badan Pertanahan Nasional No. 5 tahun 1999 yang kemudian diganti dengan Peraturan Menteri Agraria dan Tata Ruang/ Kepala Badan Pertanahan Nasional No. 9 tahun 2015 yang kemudian 
dicabut dengan Peraturan Menteri Agraria dan Tata Ruang/Kepala Badan Pertanahan Nasional No. 10 tahun 2016 , justru semakin menyulitkan kelompok masyarakat hukum adat untuk memperoleh kepastian hukum dan perlindungan terhadap tanah hak ulayat.

Jika dilihat dari sudut pandang pembaharuan hukum, istilah hak komunal yang mencoba mendefinisikan ulang dan memperluas makna hak atas tanah bagi masyarakat hukum adat mungkin sebuah terobosan hukum sebagai upaya memberikan perlindungan bagi tanah masyarakat hukum adat, tetapi dalam prateknya, penulis berpendapat justru akan berpotensi menimbulkan kerancuan dan kebingungan dan perdebatan antara istilah hak komunal dan hak ulayat. Mengingat secara hukum, peraturan perundang-undangan yang lain menggunakan definisi hak ulayat, bukan hak komunal.

Kedua, permasalahan mengenai frasa "Pendaftaran Tanah" dalam kedua peraturan menteri agraria tersebut. Peraturan Menteri Negara Agraria/Kepala Badan Pertanahan Nasional No. 5 tahun 1999 pasal 5 ayat (2) menyebutkan:

"Keberadaan tanah ulayat masyarakat hukum adat yang masih ada sebagaimana dimaksud pada ayat (1) dinyatakan dalam peta dasar pendaftaran tanah dengan membubuhkan suatu tanda kartografi, dan apabila memungkinkan, menggambarkan batas-batasnya serta mencatatnya dalam buku tanah"

Peraturan Menteri Agraria dan Tata Ruang/Kepala Badan Pertanahan Nasional No. 10 tahun 2016 tentang Tata Cara Penetapan Hak Komunal atas Tanah Masyarakat Hukum Adat dan masyarakat yang berada dalam Kawasan Tertentu pasal 18 ayat (2):

“Penetapan Masyarakat Hukum Adat Melalui Keputusan Bupati/ Walikota atau Gubernur sebagaimana dimaksud pada ayat (1) disampaikan kepada Kepala Kantor Pertanahan atau Kepala Kantor Wilayah BPN untuk ditetapkan dan didaftarkan hak komunal atas tanahnya pada Kantor Pertanahan setempat". Pasal 19 menyebutkan "Pendaftaran Hak Komunal atas tanah untuk masyarakat hukum adat dan masyarakat yang berada dalam Kawasan tertentu, atau hak komunal lainnya dilakukan sesuai dengan ketentuan peraturan perundang-undangan di bidang pendaftaran tanah". 
Frasa “..dinyatakan dalam peta pendaftaran tanah..." dalam pasal 5 ayat (2) Peraturan Menteri Negara Agraria/Kepala Badan Pertanahan Nasional No. 5 tahun 1999, dengan jelas menyebutkan bahwa tanah ulayat suatu kelompok masyarakat hukum adat setelah melalui tahapan penelitian dan penentuan, maka perlu dinyatakan dalam peta dasar pendaftaran tanah. Frasa Pasal 19 Peraturan Menteri Agraria dan Tata Ruang/Kepala Badan Pertanahan Nasional No. 10 tahun 2016, menyebutkan “ Pendaftaran Hak Komunal atas tanah untuk masyarakat hukum adat dan masyarakat yang berada dalam Kawasan tertentu, atau hak komunal lainnya dilakukan sesuai dengan ketentuan peraturan perundang-undangan di bidang pendaftaran tanah".

Merujuk kepada kedua frasa "dinyatakan dalam peta pendaftaran tanah" dan frasa "pendaftaran hak komunal atas tanah" sebagaimana telah disebutkan diatas, bertentangan dengan Peraturan Pemerintah Nomor 24 tahun 1997 tentang Pendaftaran Tanah. Karena hak ulayat maupun hak komunal bukanlah objek pendaftaran tanah. Penulis juga berpendapat apa yang dimaksudkan dengan peta dasar pendaftaran tanah sebagaimana telah disebutkan di paragraph diatas, tidak ada penjelasan lebih lanjut serta pengaturan hukum yang jelas.

3. Kebijakan-kebijakan Turunan dari Adanya Peraturan Daerah

Pada tataran ideal, sebuah peraturan daerah diikuti dengan kebijakan dari pemerintah daerah. Seperti yang terjadi di Mentawai, pasca Peraturan Daerah Kabupaten Mentawai No. 11 Tahun 2017 tentang Pengakuan dan Perlindungan Uma Sebagai Kesatuan Masyarakat Hukum Adat di Kabupaten Kepulauan Mentawai. Pemerintah daerah telah menyediakan anggaran pemberdayaan masyarakat hukum adat melalui RPJMD. Sedangkan pada masyarakat hukum adat Ammatoa Kajang, pasca Peraturan Daerah Kabupaten Bulukumba No. 9 tahun 2015 tentang Pengukuhan, Pengakuan dan Perlindungan Hak-Hak Masyarakat Adat Ammatoa Kajang tersebut, pihak PT. Lonsum telah mengembalikan hutan yang mereka kelola kepada masyarakat hukum adat Kajang. Pertemuan-pertemuan tripartit antara 
masyarakat hukum adat Kajang dengan PT. Lonsum serta pemerintah daerah, serta pemerintah daerah Kabupaten Bulukumba juga mengadakan Musrembang khusus Masyarakat Hukum Adat Kajang. ${ }^{17}$

Merujuk kepada 3 (tiga) langkah kebijakan yang dapat dilakukan pasca terbitnya peraturan daerah tentang pengakuan masyarakat hukum adat, serta hal-hal yang telah dijelaskan diatas. Pengakuan keberadaan masyarakat hukum adat melalui peraturan daerah sebagai upaya untuk memberikan perlindungan dan pemenuhan hak-hak terhadap masyarakat hukum adat bukanlah tujuan akhir, tetapi langkah awal yang harus dikuti dengan berbagai langkah-langkah kebijakan lainnya, sehingga perlindungan dan pemenuhan hak-hak masyarakat hukum adat lebih maksimal.

\section{Kesimpulan}

Peraturan daerah yang menyebutkan mengenai pengakuan masyarakat hukum adat merupakan sebuah langkah baik dari pemerintah daerah sebagai upaya memberikan perlindungan secara hukum. Peraturan daerah tersebut juga telah memberikan kepercayaan diri bagi masyarakat hukum adat akan keberadaan mereka, serta pengakuan terhadap tanah dan hutan mereka. Akan tetapi penulis berpendapat bahwa dengan menjadikan peraturan daerah menjadi satu-satunya bentuk pengakuan agar hak-hak masyarakat dilindungi menjadi kurang tepat.

Dihapuskannya Peraturan Menteri Agraria/Kepala Badan Pertanahan Nasional Nomor 5 tahun 1999 tentang Pedoman Penyelesaian Masalah Hak Ulayat Masyarakat Hukum Adat, yang kemudian diganti dengan Peraturan Menteri Agraria dan Tata Ruang/Kepala Badan Pertanahan Nasional Nomor 9 tahun 2015 tentang Tata Cara Penetapan Hak Komunal atas Tanah Masyarakat Hukum Adat dan Masyarakat yang Berada dalam Kawasan Tertentu, yang kemudian diganti dengan Peraturan Menteri Agraria dan Tata Ruang/Kepala Badan Pertanahan Nasional Nomor 10 tahun 2016 tentang Tata Cara Penetapan

\footnotetext{
17 Berdasarkan hasil wawancara dengan M. Arman, salah satu anggota penyusun Perda, dan bekerja untuk AMAN (Aliansi Masyarakat Adat Nusantara), 21 Juli 2020
} 
Ikhana Indah: Jalan Panjang Pengakuan...

Hak Komunal atas Tanah Masyarakat Hukum Adat dan Masyarakat yang Berada dalam Kawasan Tertentu, justru membuat kerancuan secara definisi dan hukum. Pengaturan hak komunal dalam dalam Permen Agraria/Ka.BPN tersebut menurut penulis tidak memiliki dasar hukum yang kuat dari ketentuan peraturan perundang-undangan diatas.

Pasca pengakuan, maka perlindungan hukum terhadap tanah milik masyarakat hukum adat (baik tanah hak ulayat maupun tanah hak komunal) perlu upaya penyelarasan hukum sehingga tidak akan menimbulkan kerancuan hukum. Penulis berpendapat perlu ada upaya hukum lain agar hak atas tanah milik masyarakat hukum adat memperoleh perlindungan hukum yang kuat, seperti penetapan. Pendaftaran hak juga masih belum memiliki kejelasan secara hukum, terutama mengenai kekuatan hukum yang benar-benar dapat memberikan perlindungan secara hukum terhadap tanah-tanah masyarakat hukum adat.

\section{Daftar Bacaan}

\section{Buku}

Darmanto dkk, Berebut Hutan Siberut: Orang Mentawai,Kekuasaan dan Politik Ekologi, (Kepustakaan Populer Gramedia 2012).

Husen Alting, Dinamika Hukum dalam Pengakuan dan Perlindungan Hak Masyarakat Adat Atas Tanah (Laksbang Pressindo 2011).

Julius Sembiring, Dinamika Pengaturan dan Permasalahan Tanah Ulayat (STPN Press 2018).

KOMNAS HAM, Inkuiri Nasional, Konflik Agraria Masyarakat Hukum Adat Atas Wilayahnya di Kawasan Hutan (KOMNAS HAM 2016).

Pemulihan Hak Ulayat-Perspektif Pemangku Kepentingan di Sumatera Barat (Huma dan Qbar 2009).

Maria SW Soemardjono, , Tanah Dalam Perspektif Hak Economi Sosial dan Budaya, (Penerbit Buku Kompas 2008).

Agenda yang Belum Selesai - Refleksi atas Berbagai Kebijakan Pertanahan, (Fakultas Hukum Universitas Gadjah Mada 2020). 
Peter Mahmud Marzuki, Penelitian Hukum (Kencana Prenadamedia Group 2005).

Soleman B Taneko, Hukum Adat Suatu Pengantar dan Prediksi Masa Mendatang (PT. Eresco Bandung 1987).

Sri Hajati, et al, Buku Ajar Hukum Adat (Prenadamedia Group 2018).

Urip Santoso, Pendaftaran dan Peralihan Hakatas Tanah (Prenadamedia Group 2010).

Yance Arizona, Antara Teks dan Konteks Dinamika Pengakuan Hukum Terhadap Hak Masyarakat Adat atas Sumber Daya Alam di Indonesia (Huma 2010).

\section{Jurnal}

Digest Epistema (2016) Volume 6/2016 Epistema.

Epistema Institute; Permudah Pendaftaran Hak Komunal Masyarakat Ada tatas Tanah, Policy Brief Volume 5 tahun 2016.

Kurnia Warman et al, 'Pola Hubungan Hukum dalam Pemanfaatan Tanah Ulayat di Sumatera Barat' (2014) Volume 26 Nomor 3 Mimbar Hukum .

\section{Tesis}

M.Arman, "Catatan Kecil Proses Penyusunan Peraturan Daerah Kab. Bulukumba No. 9 tahun 2015 tentang Pengukuhan, Pengakuan dan Perlindungan Hak Masyarakat Adat Ammatoa Kajang", AMAN, 2016, www.aman.or.id.

Siti Kotijah, Hak Gugat Masyarakat Hukum Adat dalam Pertambangan Batubara, (Disertasi Program Doktoral Ilmu Hukum Universitas Airlangga Surabaya, 2015)

Yance Arizona, dkk, Kuasa dan Hukum: Realitas Pengakuan Hukum Terhadap Hak Masyarakat Adat atas Sumber Daya Alam, Kertas Kerja Epistema No.05/2010, (Epistema Institute 2010).

How to cite: Ikhana Indah Barnasaputri, 'Jalan Panjang Pengakuan Kesatuan Masyarakat Hukum Adat Melalui Peraturan Daerah: Beberapa persoalan yang Belum Selesai' (2021) Vol. 4 No. 1 Notaire. 
22 | Ikhana Indah: Jalan Panjang Pengakuan...

--Halaman ini sengaja dikosongkan-- 